P-ISSN: 2548-5962
$\begin{aligned} & \text { DIRECTORY OF } \\ & \text { OPEN ACCESS } \\ & \text { JOURNALS }\end{aligned}$
E-ISSN: 2548-981X

\title{
Penanganan Pasien Kanker dan Risiko Infeksi selama Wabah COVID-19
}

\section{Hendry Irawan*, I Wayan Sudarsa}

Divisi Bedah Onkologi, Departemen Ilmu Bedah, Fakultas Kedokteran Universitas Udayana, RSUP Sanglah Denpasar.

*Penulis korespondensi: hendry_irawan@ rocketmail.com.

\section{DOI: https://doi.org/10.24843/JBN.2020.v04.is01.p04}

Coronavirus merupakan salah satu patogen yang menyebabkan gangguan sistem pernapasan dan pada akhir Desember 2019 di Wuhan, Provinsi Hubei, Cina terdapat pasien pneumonia dengan etiologi yang belum diketahui. Sumber penyebab infeksi tersebut adalah severe acute respiratory syndrome corona virus 2 (SARS-CoV-2). WHO (World Health Organization) menyatakan infeksi tersebut sebagai 2019 novel coronavirus disease (COVID-19). ${ }^{1,2}$ Menurut laporan WHO tanggal 3 April 2020, secara global terdapat 972.303 orang terinfeksi dan 50.322 orang meninggal, sedangkan di Asia Tenggara terdapat 5.881 orang terinfeksi dan 245 kematian. $^{3}$

Pada kondisi wabah akibat COVID-19, rumah sakit dan pelayanan medis akan terfokus untuk mengatasi infeksi tersebut. Adanya wabah COVID-19 menjadi suatu ancaman yang berpotensi pada pasien dengan gangguan sistem imun. Hal tersebut dapat menjadi pertimbangan bahwa terapi pada pasien tersebut akan membawa dampak yang menguntungkan atau merugikan pada kondisi wabah. ${ }^{4}$ Saat ini rumah sakit juga melakukan pembatasan kunjungan pasien poliklinik dan pasien rawat inap untuk mengurangi transmisi infeksi COVID-19. ${ }^{5}$

Data pasien dengan gangguan sistem imun yang terinfeksi COVID-19 masih terbatas, akan tetapi di Cina terdapat studi pasien kanker yang terinfeksi COVID-19. ${ }^{2}$ Di Cina, terdapat sekitar 4,3 juta kasus kanker yang terdiagnosis tiap tahun, dan dengan kondisi wabah pasti akan mengalami penundaan pelayanan, terutama di Wuhan. ${ }^{5}$ Saat ini negara di luar Cina mulai merasakan dampak wabah COVID-19, termasuk di Indonesia yang sudah terinfeksi 1.790 orang dengan kematian 170 orang. ${ }^{3}$ Hal tersebut akan berdampak pada diagnosis dan pengobatan pasien kanker.

Penyakit akibat kanker yang merupakan penyakit kronis yang membutuhkan pengobatan, baik operasi, kemoterapi, radioterapi, imunoterapi, dan terapi target. Hal tersebut berkaitan dengan progresivitas penyakit, rekurensi, dan eradikasi kanker. Apabila terapi pasien kanker, terutama stadium lanjut yang tertunda atau tidak diberikan rutin, maka akan memperburuk kondisi kanker.

Pasien kanker biasanya berusia lebih tua, memiliki beberapa penyakit dan dapat kompleks, serta memiliki sistem imun yang lebih rendah. Hal ini berisiko lebih tinggi menjadi sakit berat dan peningkatan mortalitas dibandingkan dengan populasi sehat dengan infeksi COVID-19. ${ }^{5}$ Di China pada 11 Februari 2020 didapatkan 72.314 kasus COVID-19 dengan 107 pasien (0,5\%) memiliki kanker dan ada 6 pasien kanker yang meninggal. ${ }^{6}$

Pada studi Liang, dkk didapatkan 18 pasien kanker dari 1.590 kasus COVD-19. 
Dari 18 pasien tersebut, paling banyak menderita kanker paru (enam orang), dua pasien tidak diketahui status pengobatan, dan 16 pasien yang sedang menjalani pengobatan. Pasien kanker dengan infeksi COVID-19 yang menjalani pengobatan, $25 \%$ (empat dari 16 pasien) mendapatkan kemoterapi atau paska operasi dalam sebulan terakhir, dan 75\% (12 pasien) merupakan penyintas kanker (cancer survivor). ${ }^{2}$ Studi Yu, dkk pada 1.524 pasien kanker yang berada di rumah sakit tersier didapatkan 12 pasien terinfeksi COVID-19 dengan dua pasien meninggal $(16,7 \%){ }^{7}$

Pada kasus infeksi COVID-19 pada pasien kanker akan menunjukkan gejala berat hingga kematian lebih tinggi dibandingkan pasien tidak kanker. Selain itu pasien kanker yang mendapatkan kemoterapi atau paska operasi dalam sebulan terakhir memiliki risiko yang tinggi dengan gejala berat sebesar $75 \%$ (tiga dari empat pasien) dibandingkan yang tidak mendapatkan kemoterapi atau operasi sebesar $43 \%$ (enam dari 14 pasien). ${ }^{2}$

Pasien kanker memiliki risiko dua kali terinfeksi COVID-19 dibandingkan populasi umum. ${ }^{7}$ Studi lain, pasien kanker memiliki risiko 5,34 (95\% CI 1,80-16,18; p=0,0026) dengan gejala berat setelah disesuaikan dengan faktor risiko lain seperti usia, jenis kelamin, hipertensi, diabetes melitus, dan penyakit paru obstruksi kronik. Pada pasien kanker akan lebih cepat 3,56 kali (95\% CI 1,65-7,69; p<0,0001) menimbulkan gejala berat (median 13 hari) dibandingkan pasien tidak kanker (median 43 hari). ${ }^{2}$ Sedangkan insiden terinfeksi COVID-19 pada pasien kanker sebesar 0,79\% (95\% CI 0,3-1,2). Hal ini lebih tinggi dibandingkan populasi umum di kota Wuhan pada waktu yang sama sebesar 0,37\% pada 17 Februari 2020. ${ }^{7}$

Pasien kanker dengan infeksi COVID-19 pada penelitian yang ada jumlahnya terbatas, akan tetapi hasil tersebut dapat memberikan kewaspadaan, strategi, dan tantangan untuk memberikan pengobatan pada pasien kanker selama wabah.

Pada wabah COVID-19 memerlukan penggunaan sumber daya dan perawatan untuk mengatasi infeksi, oleh karena itu perlu strategi untuk meminimalkan penghentian pengobatan kanker, terutama pasien dengan terapi kuratif. ${ }^{6}$

Langkah pertama dengan menciptakan lingkungan rumah sakit yang terkontrol oleh infeksi. Pasien yang datang ke ruang gawat darurat atau poliklinik dilakukan pemeriksaan suhu badan dan identifikasi ada tidaknya gangguan pernapasan. ${ }^{4,5}$ Di ruang gawat darurat, pasien dengan gangguan pernapasan dipisahkan dan diperiksa di ruangan tersendiri untuk pertimbangan adanya infeksi COVID-19. ${ }^{4}$ Kemudian dilakukan anamnesis riwayat kontak atau bepergian di area epidemik, dan lakukan pemeriksaan infeksi COVID-19., ${ }^{4,5}$ Pasien kanker yang datang ke ruang gawat darurat merupakan pasien dengan kegawatdaruratan onkologi, seperti ancaman sumbatan jalan napas, sumbatan saluran gastrointestinal, perdarahan tumoral, kompresi medula spinalis, sindoma lisis tumor, sindrom vena cava superior, hiperkalsemia, dan febril neutropenia.

Langkah kedua dengan mengatur kunjungan pasien poliklinik. Sebagai rumah sakit rujukan, pasien dapat berasal dari berbagai wilayah yang mungkin sudah terpapar infeksi COVID-19. ${ }^{4}$ Perjanjian kunjungan pasien poliklinik dapat menggunakan sistem online dan registrasi di tempat pendaftaran. Hal ini akan mengurangi jumlah pasien yang mengantri di ruang registrasi. ${ }^{5}$ Alternatif lain menggunakan telemedicine atau konsultasi online. ${ }^{4,5}$ Sistem rumah sakit dapat dimodifikasi dengan pelatihan petugas operator dan dokter untuk dapat memberikan pelayanan rawat jalan. ${ }^{4}$ Selama wabah COVID-19, perlu adanya 
pengaturan pasien poliklinik dengan mengatur jarak kontak fisik, menunda kunjungan pasien untuk operasi elektif, dan menunda kunjungan poliklinik apabila tidak mendesak. ${ }^{6}$

Menurut rekomendasi WHO, proteksi dasar untuk mencegah infeksi COVID-19 dengan melakukan cuci tangan rutin dengan sabun dan air atau dengan hand rub berbasis alkohol, menjaga jarak minimal satu meter antar orang khususnya yang memiliki gejala batuk, dan melakukan etika batuk atau bersin dengan benar. ${ }^{8,9}$ Pasien yang datang ke rumah sakit diharapkan menggunakan alat pelindung diri dengan masker dan membawa desinfektan, serta menerapkan perilaku hidup bersih dengan cuci tangan.

Langkah ketiga dengan menyiapkan ruangan khusus apabila terdapat pasien yang rawat inap dengan kecurigaan infeksi COVID-19, seperti ada gejala demam dan batuk. ${ }^{5}$ Rumah sakit juga memberlakukan aturan jarak antar pasien di ruangan minimal satu meter, memberikan edukasi untuk melakukan cuci tangan, dan etika apabila batuk atau bersin. ${ }^{8}$ Pasien yang dicurigai terinfeksi perlu dicatat dan dilakukan pemeriksaan darah lengkap, rontgen toraks, dan computed tomography scan (CT scan) toraks. ${ }^{5,8,9}$ Pasien dengan infeksi COVID-19 memiliki gambaran infiltrat dan opasifikasi pada paru yang menunjukkan gambaran pneumonia, akan tetapi sekitar $40 \%$ kasus tidak ditemukan kelainan tersebut. ${ }^{8}$ Pada CT scan dapat ditemukan opasifikasi groundglass $(88 \%)$, terjadi pada kedua paru $(87,5 \%)$, multilobular $(78,8 \%)$, dan lebih banyak terjadi pada lobus inferior dengan distribusi perifer $(76 \%) .{ }^{8}$ Pada kasus dengan pencitraan pneumonia, selanjutnya dilakukan pemeriksaan antigen dan antibodi SARSCoV-2. ${ }^{5,8,9}$

Pasien kanker yang memerlukan operasi untuk penegakan diagnosis, operasi emergency / urgency, dan terapi kuratif kanker perlu dikerjakan selama wabah ini. ${ }^{6}$ Berdasarkan hasil studi Liang, dkk, strategi penanganan pasien kanker pada wabah COVID-19 dengan menunda kemoterapi adjuvan atau operasi elektif pada kanker yang stabil. Selain itu perlu adanya perlindungan diri yang baik tiap pasien dengan kanker atau penyintas kanker dan penanganan intensif pada pasien COVID-19 dengan penyakit komorbid atau usia tua. ${ }^{2}$ Selain itu, obat antikanker yang diberikan secara intravena dapat diganti dengan obat minum apabila sediaan obat ada, seperti etoposide dan vinorelbine. Pada pasien kanker dengan kemoterapi yang memerlukan obat intravena, dapat ditunda apabila kondisi pasien tidak baik. $^{5}$

Sejak akhir Maret 2020, di Rumah Sakit Umum Pusat Sanglah Denpasar melakukan beberapa modifikasi kebijakan. Di lingkungan rumah sakit dilakukan pembatasan jumlah kunjungan poliklinik, jumlah penunggu pasien, adanya hand rub dan tempat cuci tangan di beberapa tempat, dan pembatasan jumlah pasien operasi dengan menunda operasi elektif. Poliklinik Bedah Onkologi juga melakukan modifikasi area tempat pemeriksaan pasien yang dibuat berjarak minimal satu meter antar meja pemeriksaan. Jumlah pasien yang dilakukan operasi juga dibatasi, operasi dilakukan pada pasien yang memerlukan penegakan diagnosis kanker dengan biopsi, pasien sudah mendapat kemoterapi neoadjuvan untuk operasi definitif, serta pasien yang memerlukan tindakan operasi emergensi dan urgensi. Saat ini pasien yang memerlukan kemoterapi di rumah sakit tetap dilaksanakan dengan memperhatikan kondisi pasien, baik hasil laboratorium dan status performa pasien.

Pada kondisi wabah COVID-19, maka perlu adanya perhatian khusus pada pasien kanker. Pasien dengan kanker memiliki risiko 
tinggi apabila terinfeksi COVID-19, memiliki prognosis buruk, dan lebih cepat memburuk dibandingkan pasien tidak kanker. Tindakan preventif untuk menurunkan risiko infeksi COVID-19 di rumah sakit dan penggunaan terapi anti-kanker menjadi hal yang penting diperhatikan untuk membantu pasien kanker selama wabah.

\section{DAFTAR PUSTAKA}

1. Rothan HA, Byrareddy SN. The epidemiology and pathogenesis of coronavirus disease (COVID-19) outbreak. J Autoimmun. 2020:102433.

2. Liang W, Guan W, Chen R, dkk. Cancer patients in SARS-CoV-2 infection: a nationwide analysis in China. Lancet Oncol. 2020;21:335-7.

3. World Health Organization. Coronavirus disease 2019 (COVID-19) Situation Report - 74. World Health Organization [serial online]. 3 April 2020 [diakses 4 April 2020]. Diunduh dari: https://www.who.int/docs/defaultsource/coronaviruse/situationreports/20200403-sitrep-74-covid-19mp.pdf?sfvrsn=4e043d03_4.

4. Ueda M, Martins R, Hendrie PC, dkk. Managing Cancer Care During the
COVID-19 Pandemic: Agility and Collaboration Toward a Common Goal. $J$ Natl Compr Canc Netw. 2020;18:1-4.

5. Wang Z, Wang J, He J. Active and Effective Measures for the Care of Patients With Cancer During the COVID19 Spread in China. JAMA Oncol. 2020:E1-2.

6. Al-Shamsi H, Alhazzani W, Alhuraiji A, dkk. A Practical Approach to the Management of Cancer Patients During the Novel Coronavirus Disease 2019 (COVID-19) Pandemic: An International Collaborative Group. Oncologist. 2020.

7. Yu J, Ouyang W, Chua MLK, Xie C. SARS-CoV-2 transmission in cancer patients of a tertiary hospital in Wuhan. medRxiv. 2020.

8. Susilo A, Rumende CM, Pitoyo CW, dkk. Coronavirus Disease 2019: Tinjauan Literatur Terkini. J Penyakit Dalam Indones. 2020;7:45-77.

9. Direktorat Jenderal Pencegahan dan Pengendalian Penyakit. Pedoman Pencegahan dan Pengendalian Coronavirus Disease (COVID-19) Revisi ke-4. Jakarta: Kementerian Kesehatan Republik Indonesia; 2020. 